\title{
The Noun ' $\imath$ š in Ancient Hebrew: A Marker of Essential Participation
}

\author{
David E. S. Stein \\ https://orcid.org/0000-0001-7269-6316 \\ Independent scholar \\ davidesstein@gmail.com
}

\begin{abstract}
Taking a functional, cognitive, and communication-oriented approach, this paper posits that in ancient Hebrew, the noun 'îs often played a distinctive role: to signal to an audience that its referent is essential for grasping the depicted situation. In such cases, this noun's meaning resides mainly on the level of the discourse between the speaker and the audience, rather than on the semantic level. Three types of biblical evidence are presented in support of this idea: 'îšheaded appositions, relative clauses that either serve in lieu of a substantive or modify ' $\imath \widetilde{s}$, and clauses that introduce an unquantified subset of a known group. The tests involve comparing cases where ' $i s ̌ s$ is present in a referring expression versus similar cases where it is absent. The study found that all of the studied cases with 'î́ were sketching a new or modified situation, in which this noun's referent was profiled as a key participant. In contrast, all cases without 'îs treated the referent of interest as a given element. The hypothesis accounts for 129 biblical instances of 'îs that scholars had deemed pointless or puzzling. Hence it yields a Hebrew Bible text that is more coherent and informative.
\end{abstract}

Keywords: Biblical Hebrew; Old Testament; pragmatics; functional linguistics; cognitive linguistics; 'î̌s

\section{UNISA}




\section{Introduction: The Puzzle of איש-headed Appositions ${ }^{1}$}

Consider a strong assertion by the late biblical scholar Frank Andersen (1994, 106; emphasis in original): "Everything in a text does something." If so, in the Hebrew Bible, the presence of the noun אִ must somehow be meaningful. ${ }^{2}$ Yet according to conventional wisdom, אִ is frequently meaningless.

Of the "meaningless" cases, the exemplary class is apposition. Prototypically, apposition is the juxtaposition of two noun phrases that point toward the same referent. ${ }^{3}$ Each of those two referring expressions offers useful information about their referent. Yet in the 40 cases where contribution has been regularly discounted by expert translations (Table 1) and by dictionaries (Table 2). For example, the term פִיש כָּהָן is treated just like (a priest) by itself.

Table 1: Renderings of אִיש-headed appositions in recent English translations

\begin{tabular}{|c|c|c|}
\hline Location & Referring Expression & Typical Rendering \\
\hline Exod 2:7 & אִּשָׁה מַינֶקֶת & a nurse (NJPS, NRSV, ESV) \\
\hline Lev 21:9 & אִישׁ ذּהַן & a priest (NJPS, NRSV, Alter) \\
\hline Judg 6:8 & אִיש נָבִיא & a prophet (NJPS, NRSV, ESV) \\
\hline 2 Sam 1:13 & אִיש גַּר & a sojourner (ESV, Alter) \\
\hline $1 \mathrm{Kgs} 17: 9$ & אִּשָׁה אַלְמָנָה & a widow (NJPS, NRSV, ESV) \\
\hline
\end{tabular}

1 Adapted from a paper presented to the Linguistics and Biblical Hebrew seminar, Society of Biblical Literature annual meeting, 9 December 2020. This paper's Supplemental Tables 6-10 and Excursuses 1-5 are available at https://purl.org/scholar/marker-2021. Published translations are quoted for the reader's convenience; they do not necessarily reflect my own construals.

2 Hebraists commonly gloss the masculine singular form אִיש as "man" or "person." However, any such gloss clearly fails for the cases treated herein, which is why a gloss is not provided in the body of this paper.

3 On apposition, see further Holmstedt and Jones (2017).

4 See Tables 6 and 7B (above, n. 1). 
Table 2: Treatment of אִ-headed appositions in typical biblical dictionaries

\begin{tabular}{lll}
\hline Dictionary & Language & Gist of the Treatment \\
\hline Simonis and Eichhorn 1793 & German & No translatable meaning \\
Gesenius (1829) 1835 & German & No translatable meaning \\
Koehler and Baumgartner (1967) 1995 & German & No translatable meaning \\
Koehler and Baumgartner (1967) 2001 & English & No translatable meaning \\
Schökel 1993 & Spanish & $\begin{array}{l}\text { Equivalent to indefinite } \\
\text { article, }{ }^{5} \text { or null }\end{array}$ \\
\hline
\end{tabular}

Meanwhile, grammarians' treatments of אִיש as the head term include the following claims.

- איש functions as the broadest possible term for people - a generic noun of class (Waltke and O'Connor 1990, 230, 252).

- Such appositions collocate the genus and species labels (Joüon 2006, 449; Arnold and Choi 2018, 29-31).

- In such appositions, the second member specifies the status of the first member (Van der Merwe, Naudé, and Kroeze 2017, 263).

All of these explanations imply that, in effect, the modifier noun would provide on its own. The same is true of analyses that have taken a historical approach, concluding that אִ-headed appositions are a vestigial scribal practice - transferred from occasional use of a determinative marker in Akkadian (Staples 1941; Yoder 2015). ${ }^{6}$

In addition to contradicting Andersen's principle that a literary work does not waste words, the aforementioned views are at odds with psycholinguistic findings on how apposition is processed in the mind. Researchers have concluded that in the conceptualcombination effort that is involved in the mental processing of noun-noun phrases, the contribution of the head noun is significant (Gagné and Spalding 2013). Thus, the biblical text's audience will automatically strive to wrest meaning from אִ as the head noun.

Tellingly, no explanation has yet accounted for why אִ̣ appears only occasionally with its accompanying substantive, e.g., כּּה in Lev 21:9,

5 While an indefinite article is meaningful, that meaning would be evident even without the use of in the constructions in question. Thus, Schökel's statement does not account for the noun's presence.

6 On prior scholarship regarding אִיש-headed appositions, see Excursus 1 (above, n. 1). One of the few scholars to attribute meaning to our noun as the head term in an apposition is Naomi Steinberg (2003). She correlated the different terminology for widows with the varying depictions of their economic

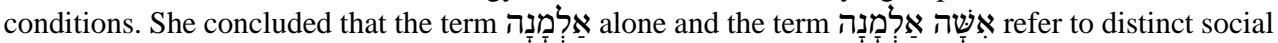
categories. Her analysis treats the appositional term as denoting a special type of widow: an "inherited widow, with son." 


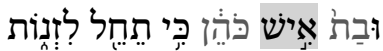

When the daughter of a priest defiles herself through harlotry (NJPS)

rather than everywhere that such substantives are used, e.g., Lev 22:12:

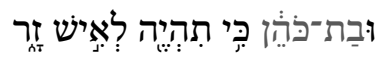

If a priest's daughter marries a layman (NJPS)

\section{Hypothesis of Meaningfulness}

A new hypothesis now explains these and other enigmatic usages of איש. The claim is that this noun has a special discourse function: it helps to manage the communication between a speaker and an audience. ${ }^{7}$ In many cases, the noun איש signals to an audience that its referent is essential for grasping the depicted situation. At issue, then, is the text's pragmatics: how words are used to communicate beyond their surface meaning. As we shall see, this hypothesis accounts not only for this noun's presence but also for its absence. Additionally, it sheds light upon 175 varied usages of אִיש that otherwise seem superfluous.

\section{Theory: Situations and Participants}

Cognitive psychologists assert that human cognition is largely devoted to keeping track of elements within situations. ${ }^{8}$ It is self-evident that among the situational elements that most consistently receive our mental attention are human participants. This abiding interest is expressed in our communication. As the late linguist Knud Lambrecht observed $(1994,46)$, "Informing a hearer of something ... necessarily involves not only participants but also something to participate in [i.e., a situation]."

Whenever a speaker depicts some situation, their audience forms a mental representation of it. Scholars call that representation a "discourse model" or "situation model." It is populated by participants whom the audience must keep track of. Figure 1 illustrates this idea.

7 This paper uses the term speaker to include also a writer, and audience to include also a reader. The audience is styled as a singular collective entity ("it").

8 According to Lawrence Barsalou and colleagues (2018, especially 2, 9), situations are precisely what the human brain primarily represents and processes. They call this "the brain's most basic function." That is, the brain situates (perceived or conceived) items within their context and it attends to the relations among those items. Situations and the relatedness of their elements lie at the heart of cognition.

9 Webber (1978, 27-29); Lambrecht (1994); Kintsch (1998); Van Berkum et al. (2007); Aitchison (2012, 89). 


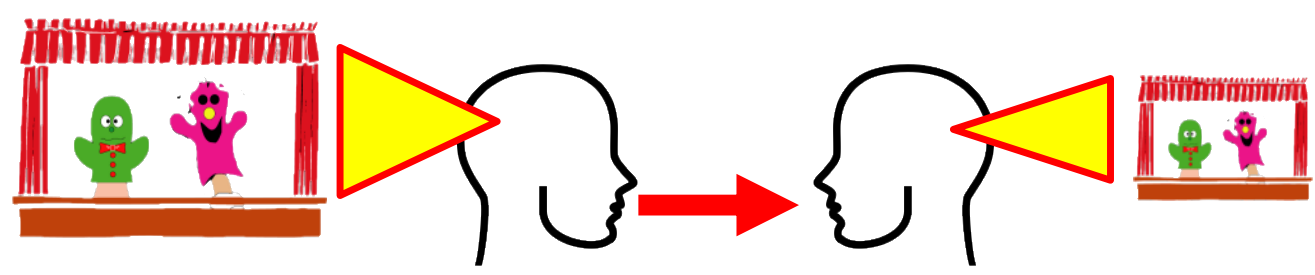

Figure 1: In successful communication, the speaker's mental representation of a depicted situation and its participants (left) is reproduced in the audience's own representation (right).

Communication is thus a matter of synchronisation between speaker and audience. Speakers are expected to help their audience to promptly grasp what is being described. They do so by giving signals that facilitate the synchrony during communication.

Taking a functional perspective, the linguist Zygmunt Frajzyngier (2011) has discussed how languages variously encode distinctions regarding participant reference. He notes that each language has its own system for making reference. For the purpose of managing communication with an audience, a speaker must harness its language's common, everyday signals. As Frajzyngier $(2011,10)$ explains, ${ }^{10}$

a large variety of [referential] functions are coded by the same lexical sources. ... The wide variety of functions coded in the domain of reference is made possible by combining these lexical sources with ... the absence of any overt coding.

In other words, reference systems can convey meaning via the presence-or-absence of a "lexical source." For this task, nouns are well suited. By their very nature, they operate partly on the discourse level. They form the heads of referring expressions - and the speaker's act of making reference is a discourse function. ${ }^{11}$

Some languages appear to have developed a special noun that signals which participants are essential to grasping the depicted situation. ${ }^{12}$ When that noun is invoked, it overtly

10 See also Frajzyngier and Shay (2003, 247-82); Frajzyngier and Jirsa (2006).

11 A referring expression prompts the audience to predict that the speaker wants to predicate something about its referent (Ramscar et al. 2010). As T. Givón explains, "Reference-denotation-is ... a mapping from linguistic expressions to individuals established verbally in the Universe of Discourse" $(2018,244)$.

12 On such a noun in English and in French, see Stein (2020). 
codes this desired signal. ${ }^{13}$ Is ancient Hebrew (the language of the Hebrew Bible) among such languages?

\section{Terminology and Methodology}

- In this paper, "essential" participants are those whose involvement defines the speaker's depicted situation. That is, in order to grasp that situation, the audience must recognise this participant's presence.

- The present study sets aside the question of what conveys about its referent's social gender, in order to ask what else is being communicated. ${ }^{14}$ It assumes that the biblical text provides evidence of the ancient language that is accurate enough for this purpose. ${ }^{15}$

- The proper criteria for evaluating whether the hypothesis is valid include: Is a label highly correlated with participants who are essential? Conversely, is it inversely correlated with those who are not essential? Furthermore, I must show that any observed usage patterns are features of the language (rather than someone's personal style, or a local lectal variant, or a scribal gloss). This requirement adds two conditions: (1) The usage patterns must be widely distributed across the biblical corpus. As a heuristic, I count the number of biblical books in which a given trait appears. ${ }^{16}(2)$ The usage patterns in question must be employed by diverse speakers. For this purpose, any distinct voice in the Bible counts as one such speaker. ${ }^{17}$

- As we shall see, my hypothesis meets the above criteria, as tested for three distinct and well-attested usage patterns for this noun.

13 Saying that the special noun in question overtly codes a signal is a more precise functional description than calling it a marked expression, as my original paper did (cf. Haspelmath 2006, 29-30).

14 The Bible's composers used the masculine form mostly in order to communicate something else about its referent besides gender (Grant 1977; Stein 2008; Stein 2020, 18-19, 142-46, 175n29, 22324). In the Bible, this term is still quite far from being fully lexically gendered (Stein 2019).

15 A relatively large amount of usage data is extant. Including the feminine form אִ ạ and plural forms, Sיש is the second most frequently occurring common noun in the Hebrew Bible-appearing nearly 3000 times. Unless otherwise noted, I restrict myself to instances where the ancient textual witnesses seem to agree on the reading. In practice, I will quote from the Masoretic Text.

16 In this study, I have adopted the classic rabbinic enumeration of 24 biblical books: Samuel, Kings, Ezra-Nehemiah, and Chronicles each count as one book, as does the Twelve Minor Prophets. While this approach does not reliably reflect a uniform compositional origin, it does respect each book's subsequent history of development and preservation.

17 Crucially, those distinct voices include the reported speech of particular narrative characters. The text's audience would predictably interpret their speech according to its own conventional parlance-while expecting the speaker's audience within the story to do the same (cf. Stein 2020, 105). 


\section{Test \#1: אִיש-headed Appositions}

Near the start of the exodus narrative, after Pharaoh's unnamed daughter finds a baby at the Nile's edge, the child's sister hazards a question (Exod 2:7):

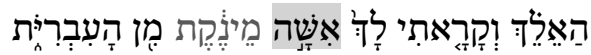

"Shall I go and call a nursing woman from the Hebrews for you...?" (SB)

"Shall I go and get you a nurse from the Hebrew women...?" (NRSV)

Elsewhere, the noun מִינֶקֶ (wetnurse) serves as a substantive on its own. So why does this girl bother to label her intended referent via apposition, as אִשָׁׁה מִינֶקֶ? I propose

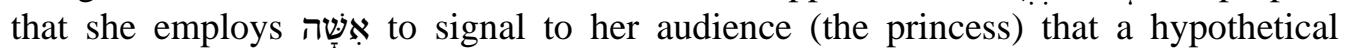
participant is being introduced whose presence is central to this new proposal, which would dramatically alter the situation. The speaker thus prompts Pharaoh's daughter to situate this new participant within her own situation model.

Although the noun phrase אִּשָה מִינֶקֶת occurs only once in the Bible, my explanation for its usage can be tested, via another personal noun, זٓנ (prostitute). That word appears by itself as a label in 21 instances, while the more prolix appositional phrase used as a referring expression in nine instances. This gives us a sizeable data set for comparison.

The distribution of this data is wide: both kinds of expression are employed in narration, in reported speech, in legislation, and in prophetic pronouncements; and both kinds appear in each of four disparate biblical books (Table 3). All of those books are

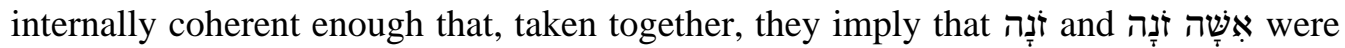
alternative expressions employed by the same speakers, who would choose between them as a matter of convention. Consequently, it is valid to ascribe a differential linguistic meaning to these two expressions.

Of the instances of standalone זָז none impacts the depicted situation itself; rather, they involve ancillary allusions to a stereotype. ${ }^{18}$ As for the instances of אִשָׁה זָנזה, all of them refer - as predicted - to a participant whose involvement defines the depicted situation. ${ }^{19}$ In one telling example, Samson goes to Gaza and has sex with a prostitute (Judg 16:1-3). The first verse of this episode relates:

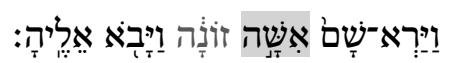

there he met a whore and slept with her. (NJPS)

18 All but one of the 21 instances make a nonspecific reference to a discourse-inconsequential type. The remaining instance (1 Kgs 22:38) refers to a specific yet stereotypical figure in the narrative background.

19 For all 30 cases, see Table 7 (above, n. 1). 
Here the prostitute in question is depicted wholly passively: both of her referring expressions appear in verbal complements; she is cast as a semantic patient; no actions or words are attributed to her; and she plays no further role in the story. Nonetheless, her involvement defines the initial situation. It simply would not exist without her presence. $^{20}$

Table 3: Reference to prostitutes, at times via apposition: comparison and distribution

\begin{tabular}{|c|c|c|c|c|}
\hline Book & Locale & Coding & Masoretic Text (Qere) & $\begin{array}{l}\text { NJPS (Torah/Prophets); } \\
\text { Fox (Proverbs) }\end{array}$ \\
\hline $1 \mathrm{Kgs}$ & $22: 38$ & Zero & 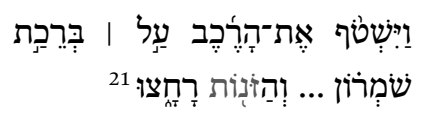 & $\begin{array}{l}\text { and they flushed out the chariot at the } \\
\text { pool of Samaria ... and the whores } \\
\text { bathed [in it] }\end{array}$ \\
\hline $1 \mathrm{Kgs}$ & $3: 16$ & Overt & 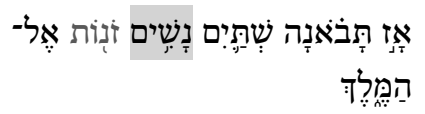 & Later two prostitutes came to the king \\
\hline Jer & $5: 7$ & Zero & 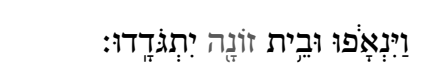 & $\begin{array}{l}\text { And [they] went trooping to the } \\
\text { harlot's house. }\end{array}$ \\
\hline Jer & $3: 3$ & Overt & 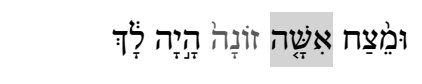 & $\begin{array}{l}\text { You had the brazenness [lit. forehead] } \\
\text { of a street woman }\end{array}$ \\
\hline Ezek & $16: 31$ & Zero & 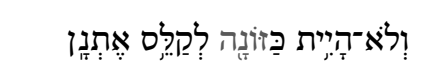 & $\begin{array}{l}\text { Yet you were not like a prostitute, for } \\
\text { you spurned fees }\end{array}$ \\
\hline Ezek & $23: 44$ & Overt & 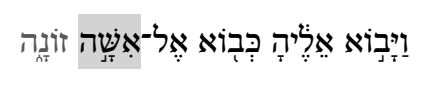 & $\begin{array}{l}\text { And they would go to her as one goes } \\
\text { to a prostitute }\end{array}$ \\
\hline Prov & $7: 10$ & Zero & 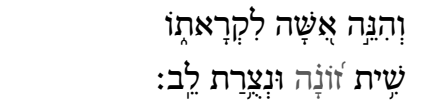 & $\begin{array}{l}\text { And now: a woman comes toward him, } \\
\text { in harlot's garb, her intent hidden. }\end{array}$ \\
\hline Prov & $6: 26$ & Overt & 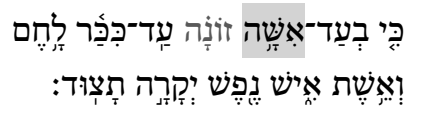 & $\begin{array}{l}\text { For a whore costs but a loaf of bread, } \\
\text { but a married woman hunts for a } \\
\text { precious life. }\end{array}$ \\
\hline
\end{tabular}

Armed with this evidence, we have grounds to claim that Moses's sister (Miriam) was indeed pointing to an essential participant by employing אִ in in her question (Exod 2:7). This construal yields a more informative text. Likewise, we can now revisit Lev 21:9 (repeated below) and explain אִ there as marking an essential participant.

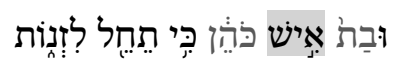

When the daughter of a priest defiles herself through harlotry... (NJPS)

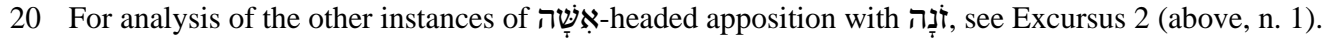

21 So also Septuagint. Although the Targum and Syriac read differently, they yield a less coherent text. 


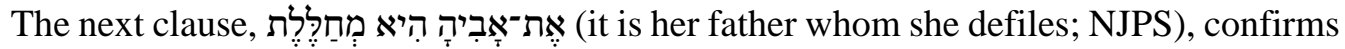
the situation-defining nature of this referent. Within the depicted situation, the father is cast as the injured party; he is then required to initiate a prosecution. Thus, his involvement is constitutive. In contrast, the wording in the ostensibly similar passage (22:12, repeated below) takes the father-priest as a given. He is merely a point of departure in depicting that situation. This accounts for why פִָּ is not modified by

$$
\text { וּבַת }
$$

If a priest's daughter marries a layman...

In short, whenever אִיש her heads an apposition, it signals that its referent is a situation-defining participant. Such a referent is cognitively essential.

\section{Test \#2: איש-headed Referring Expressions with a Relative Clause}

To what extent does אִ אִשָׁה function as a marker of essential participation? What about cases where this noun is juxtaposed with another type of substantive (not a noun), as long as those two terms are used together to point to someone, or to make a point about someone? To explore the function's reach, let us consider a second construction, as illustrated by the following near-minimal pair. While Joseph is serving as the vizier of Egypt, his steward is introduced into the discourse (Gen 43:16): ${ }^{22}$

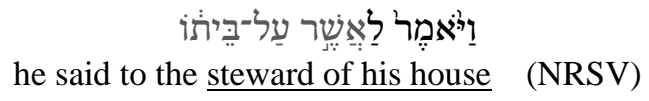

Three verses later, the same individual is referred to again, but with the addition of our noun (v. 19):

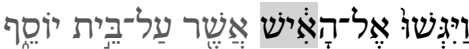

So they went up to the steward of Joseph's house (NRSV)

What accounts for the absence, and then the presence, of when referring to him? One explanation is that when the steward was introduced, his presence on the scene was treated as a given: everyone knows that a steward is a necessary part of the vizier's household staff. (For this reason, the referring expression's deixis is definite.) In contrast, in the latter instance, the narration frames a new situation that is defined in relation to the steward; he serves as a physical and conceptual point of reference for the action, as the visiting delegation approaches him.

22 According to the syntactic analysis of Robert Holmstedt (as reflected in the syntax module of Accordance Bible Software), the referring expression here is gapped - that is, it is absent yet implied by the relative clause. For convenience, I treat the relative clause as if it were the referring expression that it invokes. 
Does that explanation work elsewhere? The Bible includes 45 fairly similar caseswherein a referring expression appears within a verbal complement, in order to refer to a human being; and in that referring expression, a relative clause is headed by the relative complementiser wֶֶּ, which either serves in lieu of a substantive or modifies the noun איש. These cases are distributed widely: both formulations appear in each of six diverse biblical books and are articulated by varied voices (Table 4). I conclude that these variants form a meaningful pair of alternative expressions. Comparing the 29 cases without איש the the 16 cases with it, I find that in all cases without thent of interest is treated as a given element; in contrast, all of the cases with profile its referent as a key participant in the depicted situation. ${ }^{23}$ This finding for relative clauses suggests that when an wי-headed expression contains any kind of additional substantive - whether it be a gentilic, an adjective, or a participle - the same meaning would be expected. Namely, the head noun will function to prompt the audience's situation model to treat this referent as essential. ${ }^{24}$

Table 4: אִ-headed expressions with a relative clause: comparison and distribution

\begin{tabular}{|c|c|c|c|c|}
\hline Book & Locale & Coding & Masoretic Text (Qere) & RJPS (projected) \\
\hline Gen & $43: 16$ & Zero & 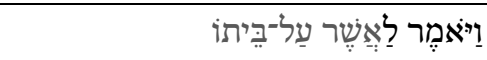 & he said to his house steward \\
\hline Gen & $43: 19$ & Overt & 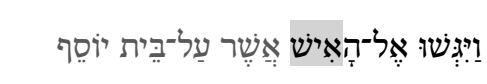 & $\begin{array}{l}\text { So they went up to the man in charge } \\
\text { of Joseph's house }\end{array}$ \\
\hline Lev & $27: 24$ & Zero & 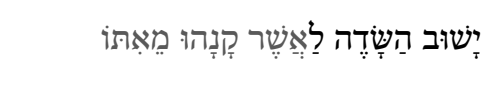 & $\begin{array}{l}\text { the land shall revert to the one from } \\
\text { whom it was bought }\end{array}$ \\
\hline Lev & $25: 27$ & Overt & 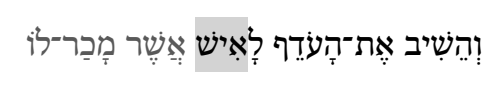 & $\begin{array}{l}\text { the difference shall be refunded to the } \\
\text { party to whom it was sold }\end{array}$ \\
\hline Num & $5: 7$ & Zero & 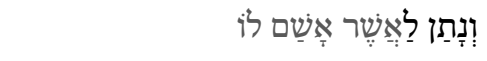 & giving it to the one who was wronged \\
\hline Num & $9: 13$ & Overt & 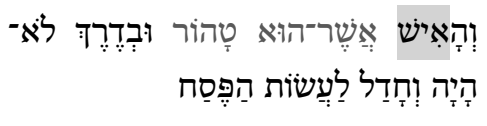 & $\begin{array}{l}\text { But if any such party who is pure and } \\
\text { not on a journey refrains from offer- } \\
\text { ing the passover sacrifice }\end{array}$ \\
\hline $1 \mathrm{Sam}$ & $30: 26-27$ & Zero & 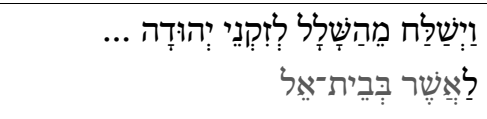 & $\begin{array}{l}\text { he sent some of the spoil to the elders } \\
\text { of Judah ... [to those] in Bethel }\end{array}$ \\
\hline $1 \mathrm{Sam}$ & $17: 27$ & Overt & 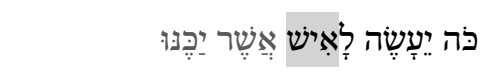 & $\begin{array}{l}\text { what would be done for the one who } \\
\text { killed him }\end{array}$ \\
\hline
\end{tabular}

23 For the full set of 45 cases, see Table 8 (above, n. 1); for discussion of additional exemplars, see Excursus 3 (above, n. 1).

24 For a list of 88 additional referring expressions in which ị is semantically superfluous and its modifier is either a gentilic, an adjective, or a participle, see Table 10 (above, n. 1). For case studies

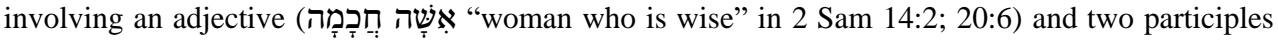
(Prov 22:7; Ezek 45:20), see Excursus 4 (above, n. 1). 


\begin{tabular}{|c|c|c|c|c|}
\hline $2 \mathrm{Kgs}$ & $10: 22$ & Zero & 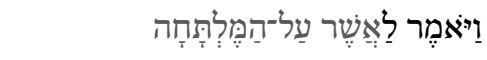 & He said to the wardrobe manager \\
\hline $2 \mathrm{Kgs}$ & $22: 15$ & Overt & 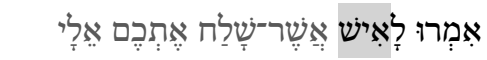 & "Say to the one who sent you to me" \\
\hline Mal & $3: 18$ & Zero & 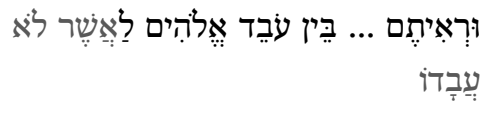 & $\begin{array}{l}\text { you shall ... see the difference ... } \\
\text { between those who have served God } \\
\text { and those who have not. }\end{array}$ \\
\hline Mal & $2: 12$ & Overt & 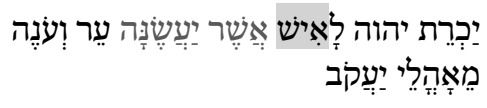 & $\begin{array}{l}\text { "May GoD leave to any man who has } \\
\text { done this no descendants dwelling in } \\
\text { the tents of Jacob" }\end{array}$ \\
\hline
\end{tabular}

\section{Test \#3: Introducing an Unquantified Subset of a Known Group}

Now I will treat a third usage pattern of interest that is quite different from the other two, in order to plumb the depths of the putative discourse function of This pattern occurs when a biblical speaker refers to an unquantified subset of a known human group, while introducing that subgroup into the discourse as a distinct entity. For example, in the book of Exodus, a narrator describes an attempt by Israelites to find manna in the wilderness as follows (Exod 16:27): ${ }^{25}$

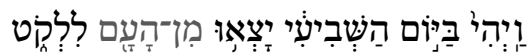

On the seventh day some of the people went out to gather ... (NRSV)

That is, out of a group that is identifiable to the audience, such as הָָָ, some number of its members are singled out. The size of that subgroup is left unspecified; what matters is simply that its members belong to the larger group.

In biblical texts, a subgroup is individuated in one of two basic ways. The main way is the partitive construction that we have just seen, in which the preposition מִ governs a label for the already-identifiable larger group. This streamlined device invokes the new subgroup only by implication.

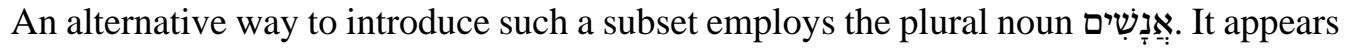
together with the partitive construction, as in the prophet Ezekiel's recounting of a visit paid to him (Ezek 14:1): ${ }^{26}$

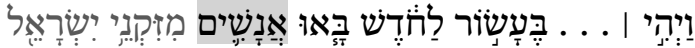

on the tenth day of the month, certain elders of Israel came (NRSV)

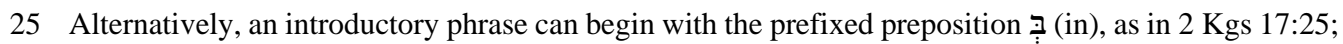
Jer 37:10. For simplicity, I write in terms of the prevailing way to indicate subgroup relationships, which is (of, from).

26 This verse's syntactic and semantic structures are similar to those in the one just adduced: a temporal clause is followed by a qatal verb of motion, and then by its subject, which involves a partitive phrase. The presence of our noun is thus the most striking difference. 


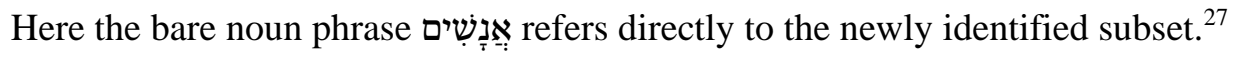

Making a reference in this second manner is more verbose. Plausibly the noun's presence overtly codes a special signal, regarding its referent's importance for the audience's grasp of the depicted situation.

In order to test this idea, I compared 40 biblical instances that use the partitive

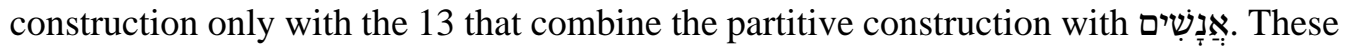
two ways to introduce a subset are distributed widely: both are employed by multiple voices; and both kinds appear in each of five disparate books (Table 5). ${ }^{28} \mathrm{I}$ again conclude that the two variant constructions were alternative expressions employed by the same Hebrew speakers.

27 As is well known among linguists, a noun regularly individuates its referents, and its plural form quantifies them. In ancient Hebrew, a bare plural noun can do both.

28 For the full set of 53 cases, see Table 9 (above, n. 1). Additional instances of the partitive-only construction may well exist, but they would not materially affect the present study's conclusions. 
Table 5: Introducing an unquantified subset of a group: comparison and distribution

\begin{tabular}{|c|c|c|c|c|}
\hline Book & Locale & Coding & Masoretic Text (Qere) & NJPS [additions in brackets] \\
\hline Num & $21: 1$ & Zero & 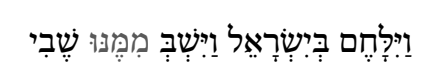 & $\begin{array}{l}\text { he engaged Israel in battle and took } \\
\text { some of them captive }\end{array}$ \\
\hline Num & $31: 3$ & Overt & 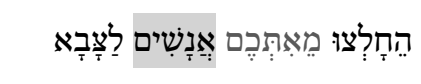 & $\begin{array}{l}\text { "Let [ } \underline{\text { some}}] \text { men be picked out from } \\
\text { among you for a campaign" }\end{array}$ \\
\hline $2 \mathrm{Kgs}$ & $25: 12$ & Zero & 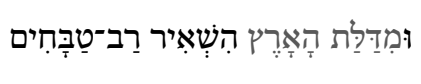 & $\begin{array}{l}\text { some of the poorest in the land were } \\
\text { left by the chief of the guards }\end{array}$ \\
\hline $1 \mathrm{Kgs}$ & $11: 17$ & Overt & 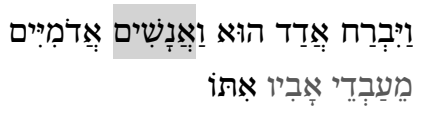 & $\begin{array}{l}\text { But Hadad, together with some } \\
\text { Edomite men, servants of his father, } \\
\text { escaped }\end{array}$ \\
\hline Jer & 39:10 & Zero & 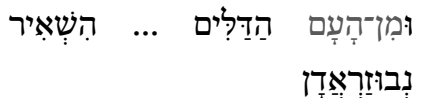 & $\begin{array}{l}\text { But some of the poorest people } \ldots \\
\text { were left } \ldots \text { by Nebuzaradan }\end{array}$ \\
\hline Jer & $26: 17$ & Overt & 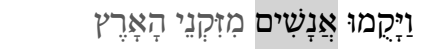 & some of the elders of the land arose \\
\hline Neh & $13: 19$ & Zero & 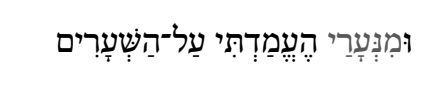 & $\begin{array}{l}\text { I stationed some of my servants at } \\
\text { the gates }\end{array}$ \\
\hline Neh & $13: 25$ & Overt & 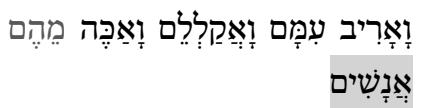 & $\begin{array}{l}\text { I censured them, cursed them, [and] } \\
\text { flogged [certain of] them }\end{array}$ \\
\hline $2 \mathrm{Chr}$ & $21: 4$ & Zero & 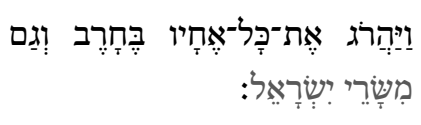 & $\begin{array}{l}\text { [He] put to the sword all his } \\
\text { brothers, as well as some of the } \\
\text { officers of Israel. }\end{array}$ \\
\hline $2 \mathrm{Chr}$ & $28: 12$ & Overt & 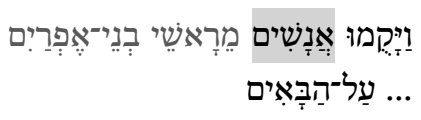 & $\begin{array}{l}\text { Some of the chief men of the } \\
\text { Ephraimites ... confronted those } \\
\text { returning }\end{array}$ \\
\hline
\end{tabular}

My analysis found that the normal approach of using only a partitive prepositional phrase correlates consistently with a treatment of its referent as a given. In contrast, all

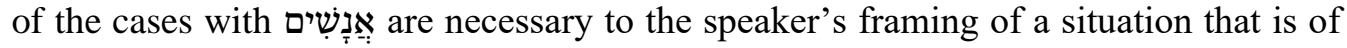
interest. It appears that this noun prompts the audience to modify its situation model as the subgroup is introduced. That is, here too the noun's presence marks a participant as cognitively essential.

\section{Discussion: Cognition and the Deployment of}

To explain varied usages of איש that conventionally have been considered uninformative, this paper has offered a communicative account: the speaker's use of איש can function to signal to an audience that its referent is essential for grasping the depicted situation. At the same time, this is also a cognitive-linguistic account, in that it 
explains the usages in question in terms of basic aspects of human cognition. ${ }^{29}$ One of these aspects has already been mentioned, namely the mind's habitual analysis of reality in terms of participants within situations. Similarly germane is the aspect of general cognition called construal. The linguist Ronald Langacker emphasises this concept in his theory known as Cognitive Grammar. He defines construal straightforwardly as "our ability to conceive and portray the same situation in alternate ways" (Langacker 2015, 120; see also 1991, 315).

In the Hebrew Bible, a speaker's construal of the depicted situation appears to determine whether איש is employed in a referring expression. Thus, איש is not used when that situation is already established and the participant in question is construed as a given. Rather, our noun is deployed only when the speaker is framing a new or dramatically altered situation. Consequently, אִ has a discourse function: it marks a participant whose involvement defines the situation of interest.

\section{Conclusion}

Three independent, robust lines of evidence support the conclusion that wherever seems uninformative (superfluous) in a referring expression - and even in some cases where it makes a semantic contribution - it is alerting us to its referent's situational import according to the speaker's construal. This approach accounts for 129 instances of איש that are otherwise pointless or puzzling: the 9 adduced in Test \#1, plus 120 similar cases cited in the online documentation. ${ }^{30}$ The proposed understanding of compelling: not only is it more comprehensive and parsimonious than any previous account, but also it yields a biblical text that is more coherent and informative-just as one would expect from a literary work. ${ }^{31}$

\section{Acknowledgement}

Prof. Christo H. J. van der Merwe provided crucial encouragement to develop the basic insight behind this paper.

29 On this procedural commitment in cognitive linguistics, see, e.g., Evans (2019, 35, 37-38).

30 See Tables 6, 7B, and 10 (above, n. 1).

31 Deployment of אִ to indicate that its referent is a situation-defining participant goes far beyond the differential coding explored in this paper. The signalling of essential participation is actually this noun's prototypical and most frequent function. Furthermore, איש is almost always the human noun that is tapped to carry out this function in Ancient Hebrew (Stein 2020). Hence of its own: a "situational noun" (Stein 2021). 


\section{Abbreviations}

ESV $=$ English Standard Version (2001)

NJPS = New Jewish Publication Society translation, 2nd ed. (1999)

NRSV $=$ New Revised Standard Version (1989)

RJPS = Revised Jewish Publication Society translation (gender-sensitive; in preparation for 2022)

SB $=$ Schocken Bible, trans. by Everett Fox (1995)

\section{References}

Aitchison, Jean. 2012. Words in the Mind: An Introduction to the Mental Lexicon. 4th ed. Malden, MA: Wiley-Blackwell.

Alter, Robert. 2018. The Hebrew Bible: A Translation with Commentary. New York: Norton.

Andersen, Francis I. 1994. "Salience, Implicature, Ambiguity, and Redundancy in ClauseClause Relationships in Biblical Hebrew." In Biblical Hebrew and Discourse Linguistics, edited by Robert D. Bergen, 99-116. Dallas: Summer Institute of Linguistics.

Arnold, Bill T., and John H. Choi. 2018. A Guide to Biblical Hebrew Syntax. 2nd ed. Cambridge: Cambridge University Press. https://doi.org/10.1017/9781139939591

Barsalou, Lawrence W., Léo Dutriaux, and Christoph Scheepers. 2018. "Moving beyond the Distinction between Concrete and Abstract Concepts." Philosophical Transactions of the Royal Society B: Biological Sciences 373: 1-11. https://doi.org/10.1098/rstb.2017.0144

Evans, Vyvyan. 2019. Cognitive Linguistics: A Complete Guide. 2nd ed. Edinburgh: Edinburgh University Press.

Fox, Everett. 1995. The Five Books of Moses: A New Translation with Introductions, Commentary, and Notes. The Schocken Bible, Vol. 1. New York: Schocken.

Fox, Michael V. 2000. Proverbs 1-9: A New Translation with Introduction and Commentary. Anchor Yale Bible 18A. New Haven, CT: Yale University Press.

Frajzyngier, Zygmunt. 2011. "Grammaticalization of Reference Systems.” In The Oxford Handbook of Grammaticalization, edited by Heiko Narrog and Bernd Heine, 625-35. Oxford: Oxford University Press. https://doi.org/10.1093/oxfordhb/9780199586783.013.0051

Frajzyngier, Zygmunt, and Bill Jirsa. 2006. "The Principle of Indirect Means in Language Use and Language Structure.” Journal of Pragmatics 38: 513-42. https://doi.org/10.1016/j.pragma.2005.03.010 
Frajzyngier, Zygmunt, and Erin Shay. 2003. Explaining Language Structure Through Systems Interaction. Typological Studies in Language 55. Philadelphia: John Benjamins. https://doi.org/10.1075/tsl.55

Gagné, Christina L., and Thomas L. Spalding. 2013. "Conceptual Composition: The Role of Relational Competition in the Comprehension of Modifier-Noun Phrases and Noun-Noun Compounds." In Psychology of Learning and Motivation, edited by B. H. Ross, 59: 97130. https://doi.org/10.1016/B978-0-12-407187-2.00003-4

Gesenius, Wilhelm. (1829) 1835. "אי." Thesaurus Philologicus Criticus Linguae Hebraeae et Chaldaeae Veteris Testamenti. 1:84-86. Leipzig: Vogelii.

Givón, T. 2018. On Understanding Grammar: Revised Edition. Philadelphia: John Benjamins. https://doi.org/10.1075/z.213

Grant, Alison M. 1977. "'Adam and 'Ish: Man in the OT.” Australian Biblical Review 25: $2-11$.

Haspelmath, Martin. 2006. “Against Markedness (and What to Replace It With).” Journal of Linguistics 42 (1): 25-70. https://doi.org/10.1017/S0022226705003683

Holmstedt, Robert D., and Andrew R. Jones. 2017. “Apposition in Biblical Hebrew: Structure and Function." KUSATU: Kleine Untersuchungen zur Sprache des Alten Testaments und seiner Umwelt 22: 21-51.

Joüon, Paul. 2006. A Grammar of Biblical Hebrew. Revised ed. Translated and revised by T. Muraoka. Subsidia Biblica 27. Roma: Editrice Pontificio Istituto Biblico.

Kintsch, Walter. 1998. Comprehension: A Paradigm for Cognition. Cambridge: Cambridge University Press.

Koehler, Ludwig, and Walter Baumgartner. (1967) 1995. "אִ." Hebräisches und Aramäisches Lexikon zum Alten Testament. 3rd ed. 1:41-42. Leiden: Brill.

Koehler, Ludwig, and Walter Baumgartner. (1967) 2001. "אָָָָׁׁ." The Hebrew and Aramaic Lexicon of the Old Testament, translated by M. E. J. Richardson from the 3rd German ed. 1:93. Leiden: Brill.

Lambrecht, Knud. 1994. Information Structure and Sentence Form: Topic, Focus, and the Mental Representations of Discourse Referents. Cambridge Studies in Linguistics 71. Cambridge: Cambridge University Press. https://doi.org/10.1017/CBO9780511620607

Langacker, Ronald W. 1991. Concept, Image, and Symbol: The Cognitive Basis of Grammar. Berlin: Mouton de Gruyter. 
Langacker, Ronald W. 2015. "Construal.” In Handbook of Cognitive Linguistics, edited by Ewa Dąbrowska and Dagmar Divjak, 120-43. Handbooks of Linguistics and Communication Science 39. Berlin: De Gruyter Mouton.

Ramscar, Michael, Daniel Yarlett, Melody Dye, Katie Denny, and Kirsten Thorpe. 2010. "The Effects of Feature-Label-Order and Their Implications for Symbolic Learning." Cognitive Science 34 (6): 909-57. https://doi.org/10.1111/j.1551-6709.2009.01092.x

Schökel, Luis Alonso. 1993. "אִ." Diccionario Bíblico Hebreo-Español. Valladolid: Editorial Trotta.

Simonis, Johann, and Johann Gottfried Eichhorn. 1793. "אִ." Lexicon Manuale Hebraicum et Chaldaicum, 105-8. Halle: Curti.

Staples, W. E. 1941. "The Reading of Hebrew.” The American Journal of Semitic Languages and Literatures 58 (2): 139-45. https://doi.org/10.1086/370600

Stein, David E. S. 2008. "The Noun איש ('îs) in Biblical Hebrew: A Term of Affiliation." Journal of Hebrew Scriptures 8 (Article 1): 2-24. https://doi.org/10.5508/jhs.2008.v8.a1

Stein, David E. S. 2019. "When Did the Biblical Hebrew Noun 'î̌ Become Lexically Gendered?" Paper presented to the Linguistics and Biblical Hebrew seminar, Society of Biblical Literature annual meeting; San Diego, 24 November. https://purl.org/stein/lexgender

Stein, David E. S. 2020. "Relational Meanings of the Noun ('îš) in Biblical Hebrew." PhD diss., Stellenbosch University. https://scholar.sun.ac.za/handle/10019.1/107875

Stein, David E. S. 2021. "The Situational Noun in Ancient Hebrew: A New Understanding of אִ." Paper presented to the Biblical Lexicography section, Society of Biblical Literature annual meeting; San Antonio, 22 November. https://purl.org/stein/situational

Steinberg, Naomi. 2003. "Romancing the Widow: The Economic Distinctions Between the 'Almānā, the 'Išša-'almānā, and the 'Éšet-Hammēt." In Women and Property in Ancient Near Eastern and Mediterranean Societies, edited by Deborah Lyons and Raymond Westbrook, 1-15. Cambridge, MA: Center for Hellenic Studies, Harvard University. https://www.chs.harvard.edu/wp-content/uploads/2020/07/women_property_steinberg.pdf

Van Berkum, Jos J. A., Arnout W. Koornneef, Marte Otten, and Mante S. Nieuwland. 2007. "Establishing Reference in Language Comprehension: An Electrophysiological Perspective." Brain Research 1146 (1): 158-71. https://doi.org/10.1016/j.brainres.2006.06.091

Van der Merwe, Christo H. J., Jackie A. Naudé, and Jan H. Kroeze. 2017. A Biblical Hebrew Reference Grammar. 2nd ed. London: Bloomsbury T\&T Clark. 
Waltke, Bruce K., and Michael Patrick O’Connor. 1990. An Introduction to Biblical Hebrew Syntax. Winona Lake, IN: Eisenbrauns.

Webber, Bonnie Lynn. 1978. “A Formal Approach to Discourse Anaphora.” PhD diss., Harvard University. BBN-3761, Advanced Research Projects Agency, U.S. Office of Naval Research. https://apps.dtic.mil/dtic/tr/fulltext/u2/a055671.pdf

Yoder, Tyler R. 2015. “An Anomalous Form of Northwest Semitic Apposition and Its Ancient Near Eastern Context.” Journal of Northwest Semitic Languages 41 (1): 101-15. 